\title{
THE MOHR-COULOMB FRICTION ANGLE OF GRANULAR SOILS UNDER DIFFERENT STRESS CONDITIONS
}

\author{
Justyna Sławińska \\ Institute of Hydro-Engineering, Polish Academy of Sciences, Gdańsk
}

\begin{abstract}
The friction angle $\varphi^{\prime}$ describes the failure state of soil and it can be determined from the Mohr-Coulomb criterion. In the classical approach, the friction angle $\varphi^{\prime}$ is a physical feature of soil, and its value depends only on the initial density. The paper aims at experimental verification of this assumption. The experimental results show that the value of the friction angle $\varphi^{\prime}$ also depends on the stress path that leads to the failure of the sample. The experiments were performed in a classical triaxial apparatus and a true triaxial apparatus. Series of compression tests for constant initial soil density, were performed for three different states of stress: axisymmetric stress conditions, 3D stress conditions and plane strain conditions.
\end{abstract}

Key words: True Triaxial Apparatus, plane strain conditions, the Mohr-Coulomb criterion

\section{INTRODUCTION}

Basic strength parameters available to geotechnical engineers for computational analyses are the effective friction angle $\varphi^{\prime}$ and effective cohesion $c^{\prime}$. The stiffness of soil is described by the compressibility modules $M$ (primary and secondary) and Poisson's ratio $v$ or the Young modulus $E$. The constitutive model in which these parameters sufficiently describe the failure state of soil is the Mohr-Coulomb (M-C) criterion. This criterion is often used because of its simplicity and the small number of parameters needed for model calibration.

The friction angle $\varphi^{\prime}$ in the M-C criterion is determined by shear tests of soil under axisymmetric conditions. In the M-C model it is assumed that the friction angle $\varphi^{\prime}$ is independent of the stress path. Therefore, the value of the friction angle from axisymmetric tests is the same as the one assumed, for example, under plane strain conditions. However, experimental results show that the friction angle depends on stress conditions at failure. Some of the first comparisons between triaxial and plane strain experimental results are described in Cornforth (1964), Hambly (1969), Rowe (1969), Lee (1970), Green (1971), Lade (1978), Yasin, Umetsu, Tatsuoka, Arthur and Dunstan (1999), Wanatowski and Chu $(2006,2007)$. Experimental investigations have proven that the shear strength of granular soils under plane strain conditions is higher than that under axisymmetric conditions. Going further, shear tests performed under full 3D stress conditions show that the strength of soil is higher than it is under axisymmetric conditions, but smaller than it is under plane strain conditions (Lade and Duncan, 1975; Kirkgard and Lade, 1993). The dependency of the friction angle on the state of stress has led to the development of many alternative failure criteria of soil (Lade and Duncan, 1973; Matsuoka and Nakai, 1974).

The purpose of this publication is to prove that the Mohr-Coulomb criterion is insufficient to describe the

$\varpi_{\text {stynaju@ibwpan.gda.pl }}$ 
failure state of soil in general. This is due to the fact that the friction angle is different under different stress conditions. The author focuses on three different stress compression conditions: axisymmetric conditions, 3D stress conditions and a particular 3D case: plane strain. Tests were conducted in each state of stress on soil samples with very similar initial density index, ranging from 0.76 to 0.88 . Axisymmetric tests were performed in a classical triaxial apparatus, and 3D tests in a true triaxial apparatus.

\section{CLASSICAL TRIAXIAL APPARATUS (CTA)}

The CTA is a laboratory device for studying the behaviour of soil under axisymmetric stress conditions. A scheme of the stresses applied to the soil sample under axisymmetric stress conditions is presented in Figure 1: $\sigma_{1}$ is the normal vertical stress, $\sigma_{3}$ is the normal horizontal stress. The soil sample has a cylindrical shape with a height of $80 \mathrm{~mm}$ and a diameter of $38 \mathrm{~mm}$. The measuring system includes special gauges for the local measurement of both vertical and lateral strains. A sample prepared for testing with gauges installed is presented in Figure 2.

In this kind of apparatus, it is possible to investigate the behaviour of soil under special stress conditions in which there is one value of lateral stress $\sigma_{3}$ applied radially to the specimen. A CTA (Menzies, 1988) with Bishop's and Weseley's chambers (Bishop and Wesley, 1975) is available at the Institute of Hydro-Engineering. The device has been manufactured by GDS Instruments. The vertical load $\sigma_{1}$ is applied through the movement of the table on which the sample is mounted. The movement is in forced by

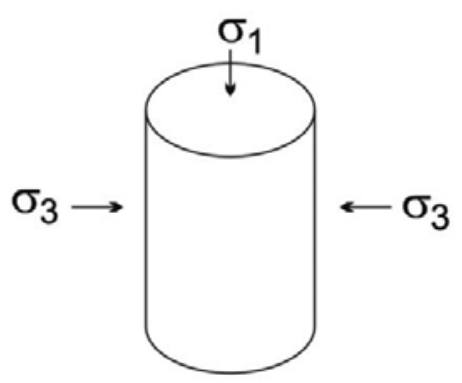

Fig. 1. Stress state in a soil sample under axisymmetric stress conditions

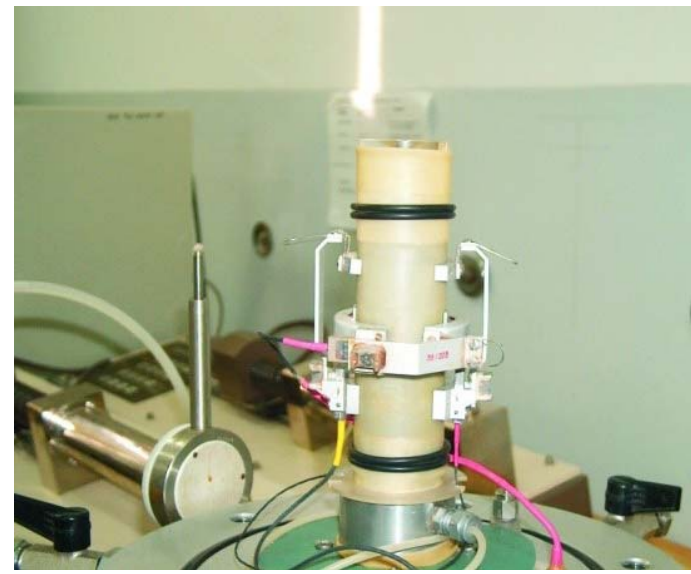

Fig. 2. A soil sample prepared for testing in a classical triaxial apparatus with gauges installed (Świdziński, 2006)

increasing the pressure in the lower pressure chamber. The rigid mounting of the piston in the upper part of the chamber results in the development of a vertical compressive force. The lateral stress $\sigma_{3}$ is applied by water pressure in the chamber. More detailed information on the CTA is available in Świdziński (2006) or Świdziński and Mierczyński (2002). A soil sample during an experiment is shown Figure 3.

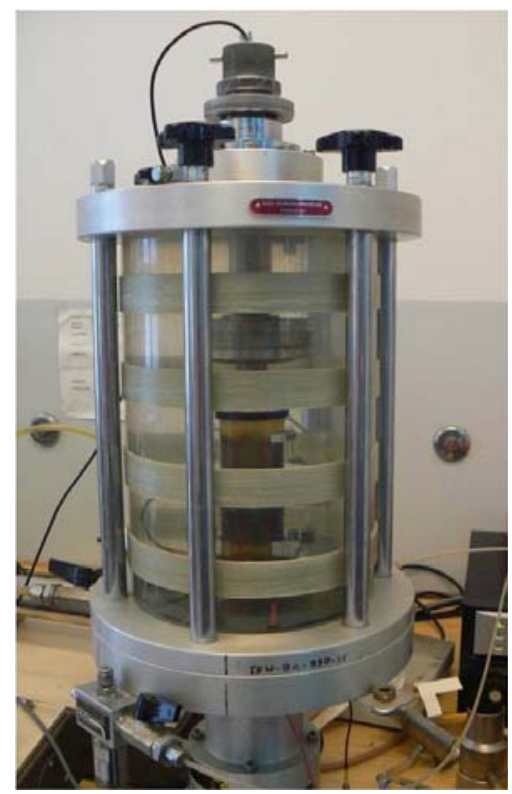

Fig. 3. A sample during a test in the classical triaxial apparatus 


\section{TRUE TRIAXIAL APPARATUS (TTA)}

The TTA available at the Institute of Hydro-Engineering has also been manufactured by GDS Instruments. It is an electro-mechanical laboratory system (presented in Figure 4) which offers more possibilities to study the behaviour of soil than the CTA does. The TTA makes it possible to investigate the behaviour of soil under full stress conditions, and it controls normal stresses and strains independently.

A scheme of the stresses applied to a soil sample under full stress conditions in the TTA is presented in Fig- ure 5. The vertical normal stress $\sigma_{1}$ is applied via rigid platens, while the horizontal normal stresses are applied by rigid platens $\left(\sigma_{2}\right)$ and a flexible membrane $\left(\sigma_{3}\right)$.

The application of load or displacement via the rigid platens $\left(\sigma_{1}, \sigma_{2}\right)$ is controlled by electro-mechanical actuators. The normal stress applied via the flexible membrane $\left(\sigma_{3}\right)$ is controlled by a pneumatic pressure controller (GDS EMTAA Handbook, 2013). A rectangular specimen measuring $150 \times 75 \times 75 \mathrm{~mm}$ is placed in the membrane. The flexible rubber membrane is used to seal the soil specimen. Figure 6 shows a soil sample before the test and the assumed coordinate sys-

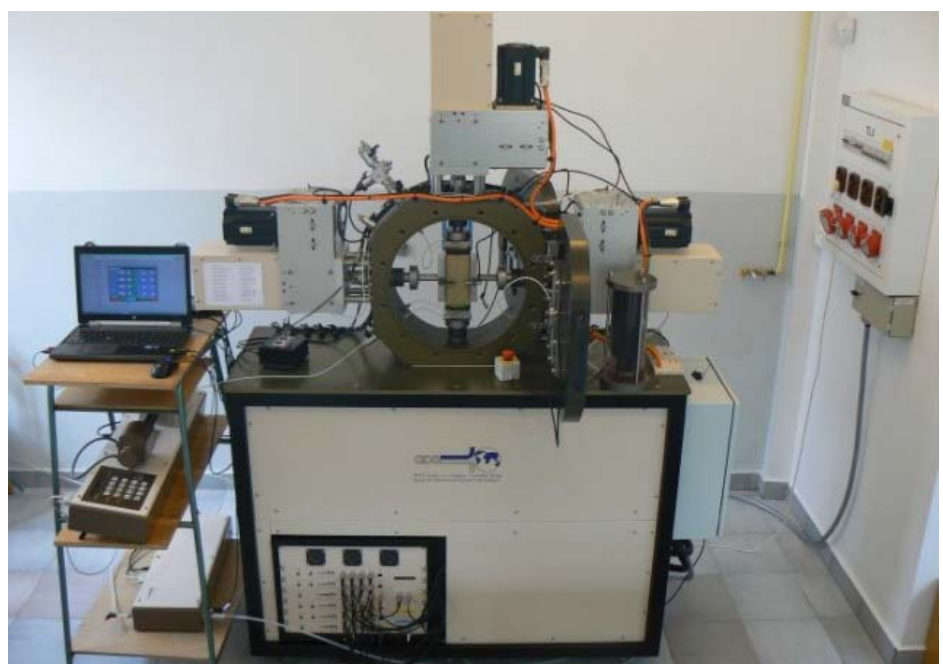

Fig. 4. True Triaxial Apparatus

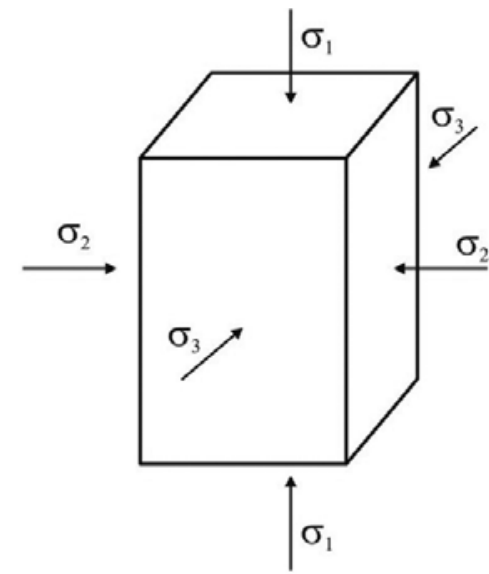

Fig. 5. Stress state in a soil sample under full stress con ditions

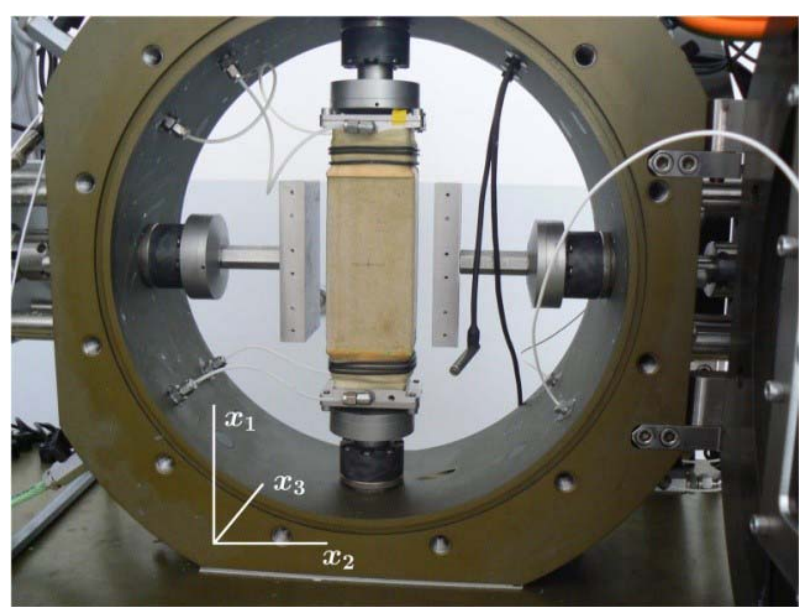

Fig. 6. A soil sample before a TTA test and the assumed coordinate system (Sawicki, Sławińska, Mierczyński i Smyczyński, 2016) 
tem $x_{1} x_{2} x_{3}$. The directions of the axes coincide with the normal stresses, namely: $x_{1}$ with the vertical stress $\sigma_{1}$, and $x_{2}, x_{3}$ with the lateral stress $\sigma_{2}, \sigma_{3}$, respectively. Vertical and lateral stresses $\left(\sigma_{1}, \sigma_{2}\right)$ are controlled by the corresponding actuators and plates. The lateral stress $\sigma_{3}$ is applied through the water pressure in the chamber. The side plates (in $x_{2}$ direction) can be used to set plane strain conditions. All TTA functions are controlled by a computer with a special software. Soil deformations are calculated by a program which controls the movement of the plates (in $x_{1}$ and $x_{2}$ directions) and the signal from proximity sensors (in $x_{3}$ direction). First experimental data from a test done in the TTA under plane strain conditions were published in Sawicki et al. (2016).

\section{THE MOHR-COULOMB CRITERION}

Coulomb, in his investigations of retaining walls, proposed the failure criterion for soils (Heyman, 1972):

$$
|\tau|=S_{0}+\sigma \tan \phi
$$

where:

$S_{0}$ - cohesion,

$\phi-$ angle of friction.

In the main stress space for non-cohesive soils, Eq. (1) can be written as follows:

$$
\left(\sigma_{\max }-\sigma_{\min }\right)-\left(\sigma_{\max }-\sigma_{\min }\right) \sin \varphi^{\prime}=0
$$

where

$\sigma_{\max }, \sigma_{\min }$ are the largest and the smallest values of the normal stress, respectively, the "plus" sign denotes compression, and $\varphi^{\prime}$ is the friction angle. On the deviatoric plane, the M-C yield surface corresponds to a hexagonal contour in which the same value of the friction angle is mobilized, $\varphi^{\prime}=$ const.

\section{EXPERIMENTAL RESULTS}

All experiments were performed on the "Skarpa" quartz sand, the main characteristics of which are presented in Table 1.

Six shear tests were conducted under drained conditions. The soil samples were prepared in a mem- brane-lined split moulder by the air pluviation method. Each experiment was carried out in two phases. In the first phase, pressure was applied in the chamber. In the second phase, the main test was performed, that is, shear at $\sigma_{3}=$ const. All soil samples were sheared at a constant rate of vertical deformation of $10 \% \cdot \mathrm{h}^{-1}$. All values of stresses are in $\mathrm{kPa}$. Tests under axisymmetric conditions (HZCM4, ZH7CM) were performed in the CTA. The results of these experiments are taken from Świdziński (2006). Tests under full 3D stress conditions (17CM9 3D, 18CM10 3D) and under plane strain conditions (28CM12 PSO, 31CM13 PSO) were carried out by the author in the TTA. $I_{D}^{0}$ denotes the density index, directly before the test. Under plane strain conditions, side plates were used to prevent soil deformations in the $x_{2}$ direction. In this case, the lateral stress $\sigma_{2}$ can only be read but cannot be applied. A scheme of this situation is presented Figure 7.

Table 1. Characteristics of "Skarpa" sand

\begin{tabular}{lc}
\hline Parameter & Value \\
\hline Mean particle size & $D_{50}=0.42 \mathrm{~mm}$ \\
\hline Uniformity coefficient & $U=2.5$ \\
\hline Minimum void ratio & $e_{\min }=0.432$ \\
\hline Maximum void ratio & $e_{\max }=0.677$ \\
\hline
\end{tabular}

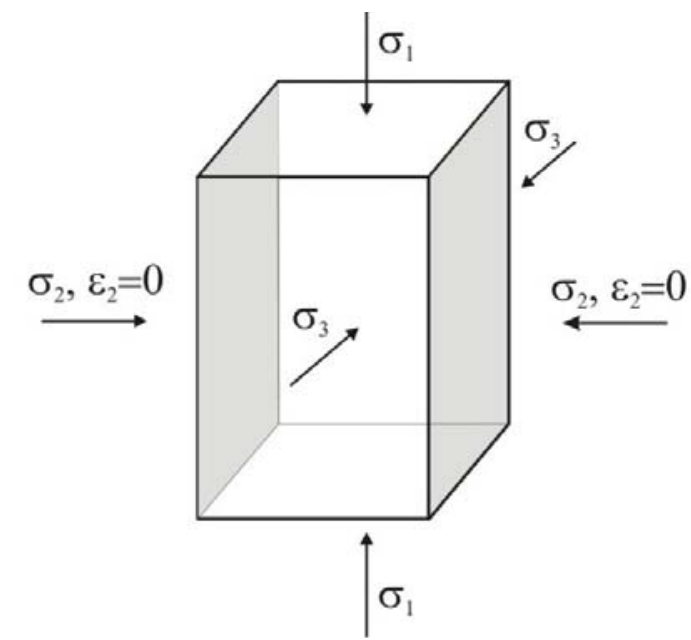

Fig. 7. A scheme of soil sample loading under plane strain conditions. Soil deformations in the $x_{2}$ direction are prevented 
Figures 8 and 9 present the results from HZCM4 and $\mathrm{ZH} 7 \mathrm{CM}$ experiments and show the stress paths leading to failure (a) and volumetric strain $\varepsilon_{v}$ (b) for the shearing under axisymmetric conditions. The results are shown in the $\varepsilon_{1}-\sigma_{1}, \sigma_{3}$, (a) and $\varepsilon_{1}-\varepsilon_{v}$ (b) coordinate system, where $\varepsilon_{1}$ denotes axial strains. $\sigma_{\max }$ is the largest value of the normal stress, in the axisymmetric compression, it is always $\sigma_{1}$. The critical value $\sigma_{1}^{\max }$ corresponds to $\sigma_{1}^{\min }$. Under these stress conditions, $\sigma_{1}=\sigma_{2}$. Detailed values of stresses in the failure state of the soil are listed in Table 2, where $p^{\prime}, q$, $\theta$ are the stress invariants: mean effective stress, stress deviator and the Lode angle, respectively (Cudny and Binder, 2005).

Figures 10, 12 present results of 28CM12 PSC and 31CM13 PSC experiments and show the stress paths leading to failure under plane strain conditions. In this case, it is the full state of stress, so the experimental a

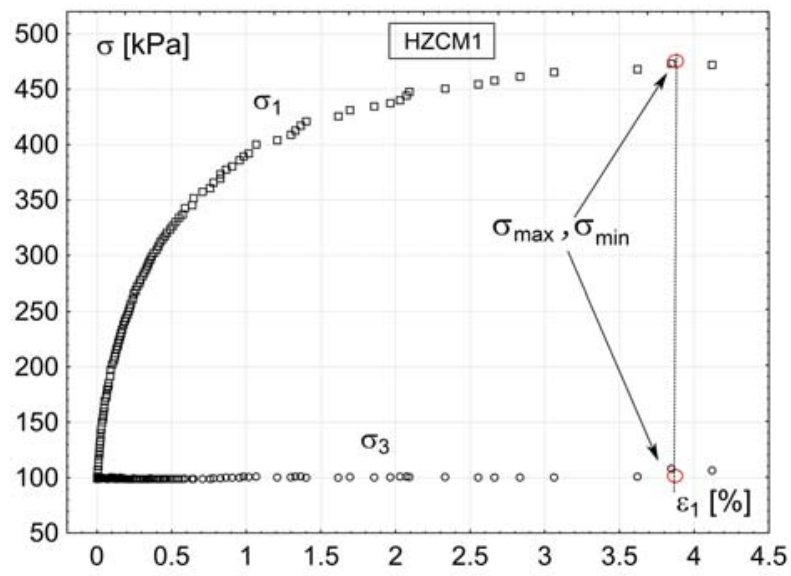

b

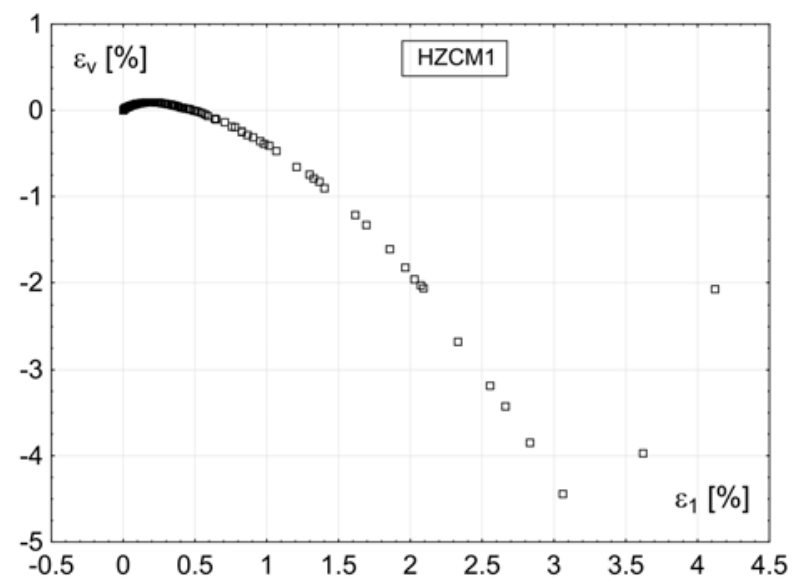

Fig. 8. Stress path leading to the failure state (a) and volumetric strain (b) under axisymmetric conditions with $\sigma_{3}=$ const $=100 \mathrm{kPa}$

a

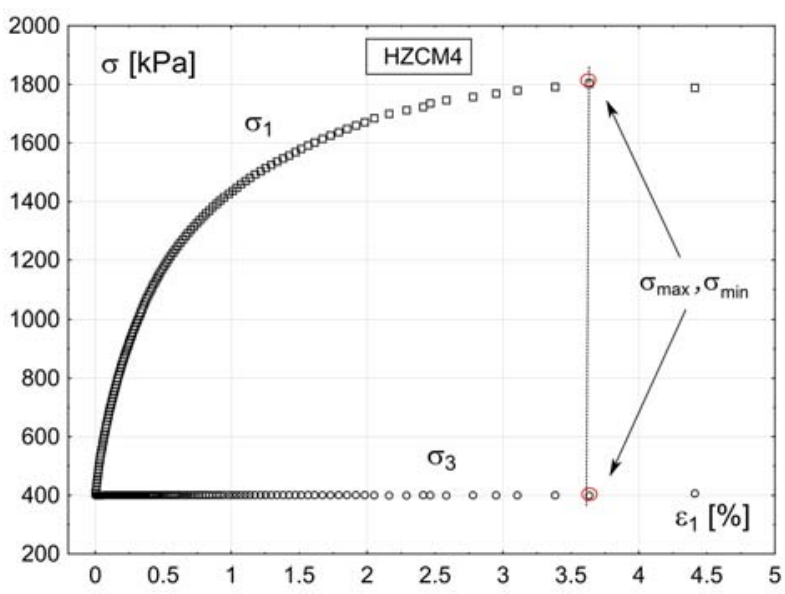

b

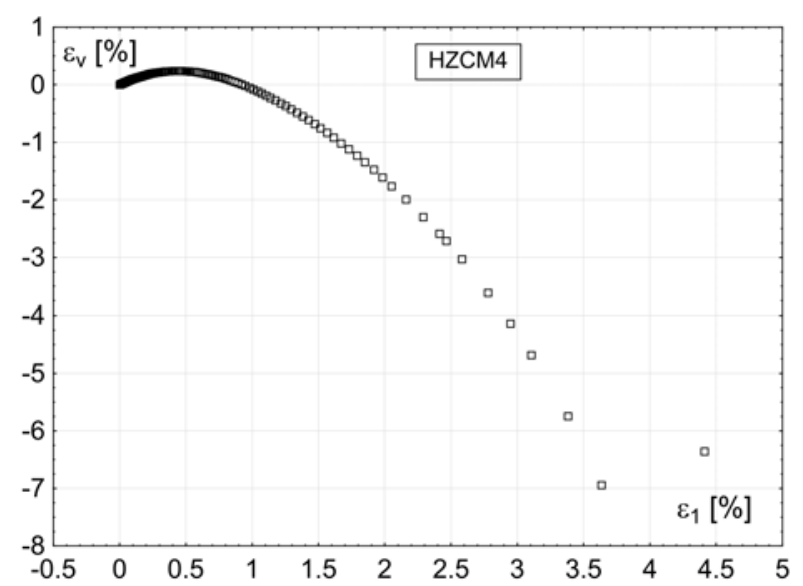

Fig. 9. Stress path leading to the failure state (a) and volumetric strain (b) under axisymmetric conditions with $\sigma_{3}=$ const $=400 \mathrm{kPa}$ 


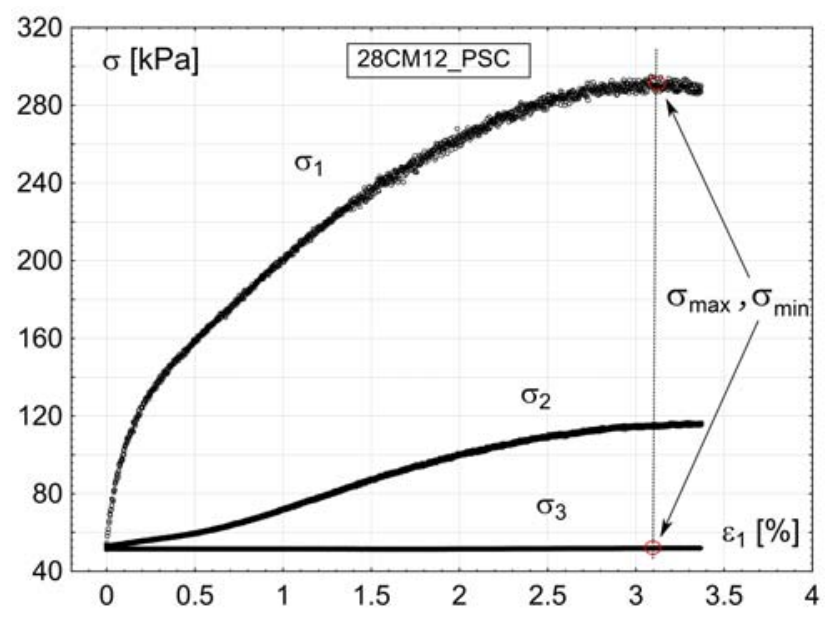

Fig. 10. Stress path leading to the failure state under plane strain conditions with $\sigma_{3}=$ const $=50 \mathrm{kPa}$

a

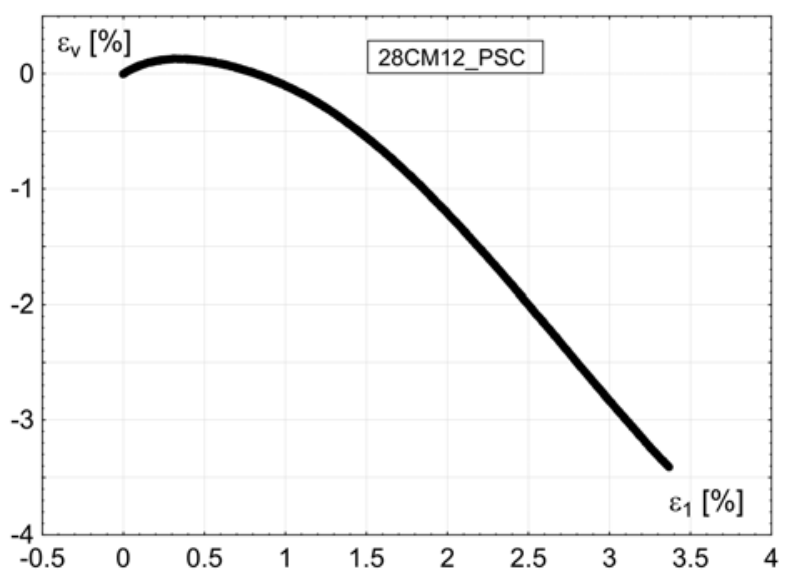

$\mathrm{b}$

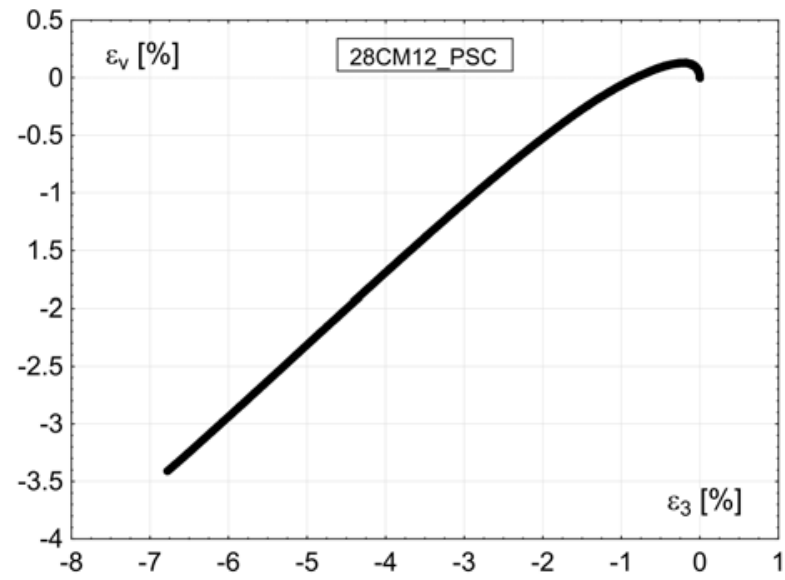

Fig. 11. Relationship: $\varepsilon_{1}-\varepsilon_{v}$ (a) and $\varepsilon_{3}-\varepsilon_{v}$ (b) for the shearing under plane strain conditions, $\sigma_{3}=$ const $=50 \mathrm{kPa}$

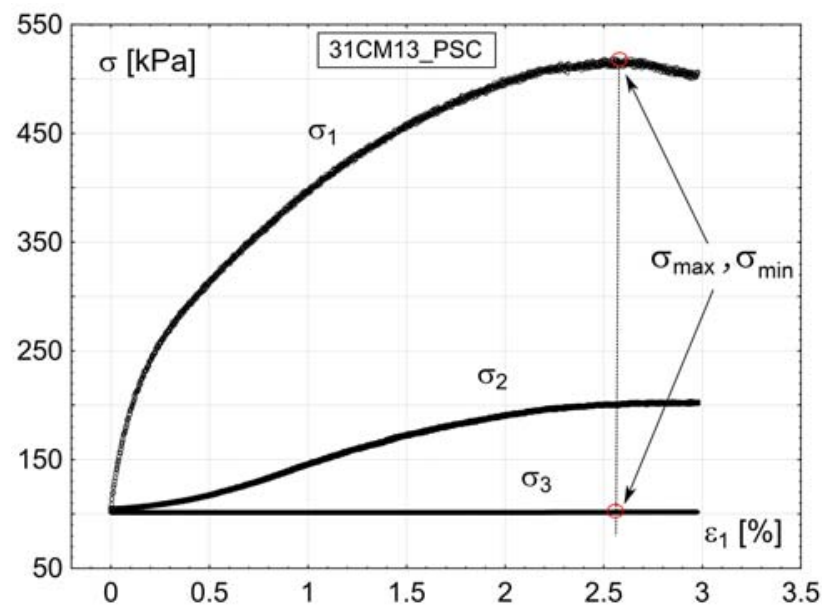

Fig. 12. Stress path leading to the failure state under plane strain conditions with $\sigma_{3}=$ const $=100 \mathrm{kPa}$ 
results are shown in the $\varepsilon_{3}-\sigma_{1}, \sigma_{2}, \sigma_{3}$, coordinate system. The stress $\sigma_{2}$ is an intermediate stress, and thus, to calculate the C-M friction angle, the values of $\sigma_{1}$ and $\sigma_{3}$ are needed. Detailed values of stresses at the failure state of the soil in those experiments are given in Table 2. Figures 11, 13 show the relationships: $\varepsilon_{1}-\varepsilon_{v}$ (a) and $\varepsilon_{3}-\varepsilon_{v}$ (b) for 28CM12 PSC and 31CM13 PSC experiments, respectively.

Figures 14, 16 present the results of 17CM9 3D and $18 \mathrm{CM} 103 \mathrm{D}$ experiments and show the stress paths leading to failure under 3D stress conditions. The experimental results are shown in the $\varepsilon_{1}-\sigma_{1}, \sigma_{2}$, $\sigma_{3}$ coordinate system. The friction angle $\varphi^{\prime}$ was determined based on the peak strength and the failure state corresponds to the greatest value of $\sigma_{1}$. Samples were prepared with due care and repeatability, which excludes appearance of peak values caused by the initial state of the sample. Detailed values of stresses corresponding to the failure state of the soil in those experiments are listed in Table 2. It can be noticed that the mobilization of the $\sigma_{2}$ stress occurs after reaching the failure state of soil. The stress $\sigma_{2}$ rises and finally exceeds the value of the $\sigma_{1}$ stress. This is due to the fact that the soil can no longer bear the stresses in the

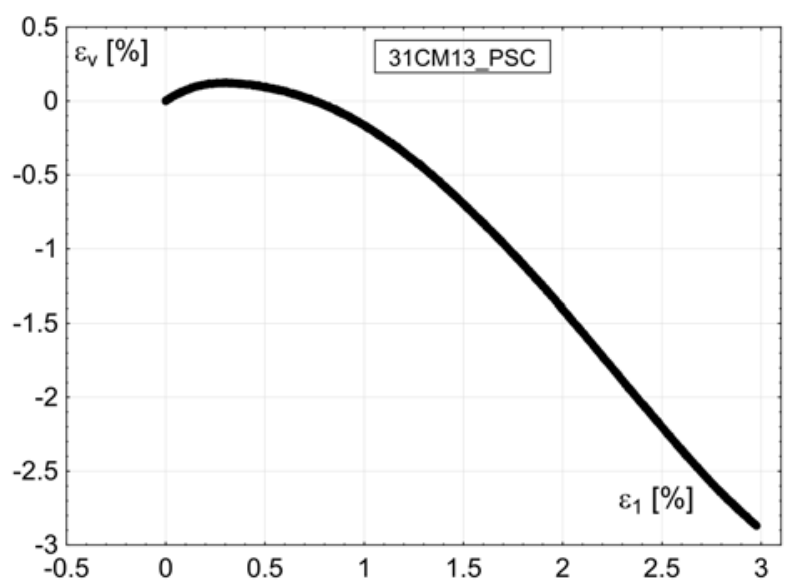

b

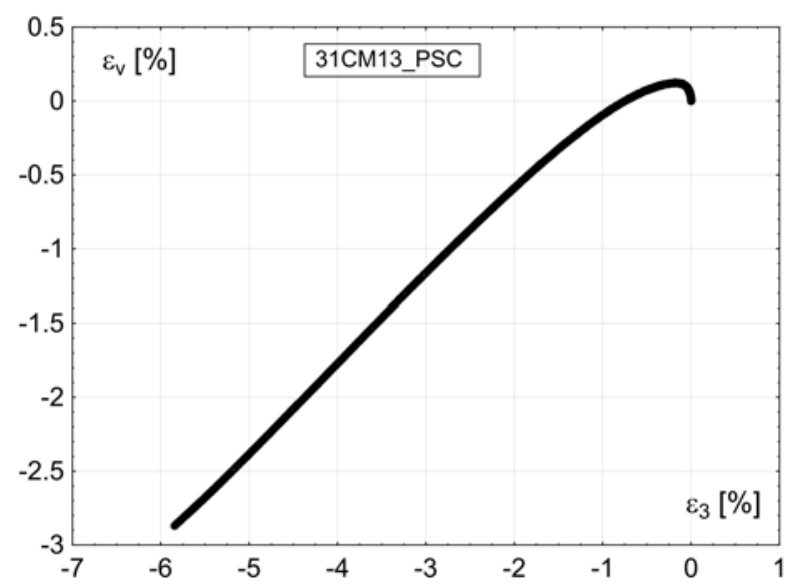

Fig. 13. Relationship: $\varepsilon_{1}-\varepsilon_{v}$ (a) and $\varepsilon_{3}-\varepsilon_{v}$ (b) for the shearing under plane strain conditions, $\sigma_{3}=$ const $=100 \mathrm{kPa}$

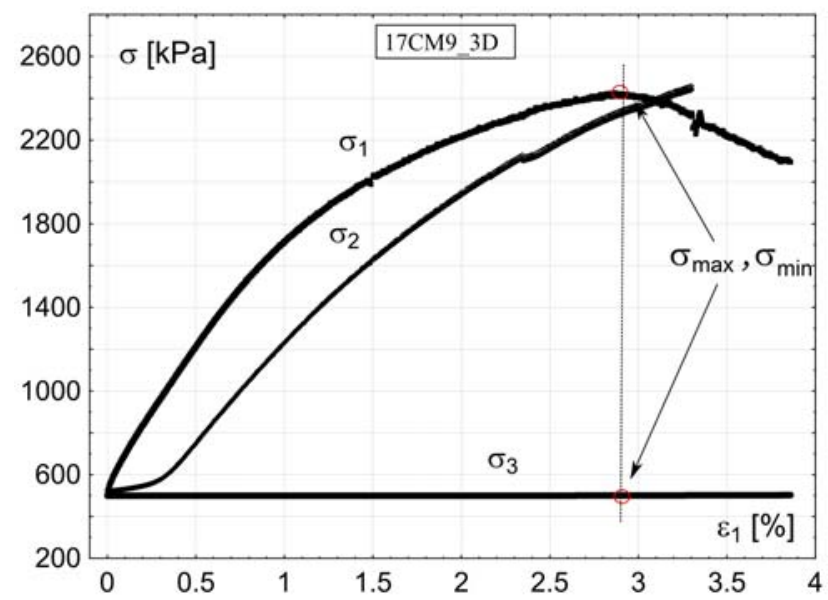

Fig. 14. Stress path leading to the failure state (a) and under full $3 \mathrm{D}$ conditions with $\sigma_{3}=$ const $=500 \mathrm{kPa}$ 
Sławińska, J. (2018). The Mohr-Coulomb friction angle of granular soils under different stress conditions. Acta Sci. Pol. Architectura, 17 (4), 51-60. doi: 10.22630/ASPA.2018.17.4.40

Table 2. Experimental results: values of stresses corresponding to the failure state

\begin{tabular}{lcccccccc}
\hline Test & $I_{D}^{0}$ & $\sigma_{1}^{\max }$ & $\sigma_{2}$ & $\sigma_{1}^{\min }$ & $\varphi^{\prime}\left[{ }^{\circ}\right]$ & $p^{\prime}$ & $q$ & $\theta\left[^{\circ}\right]$ \\
\hline HZCM4 & 0.81 & 1791 & 400 & 400 & 39.4 & 863.7 & 1391 & 0 \\
\hline HZCM1 & 0.76 & 465 & 100 & 100 & 40.3 & 221.7 & 365 & 0 \\
\hline \multicolumn{7}{c}{ Axisymmetric conditions } \\
\hline 17CM9_3D & 0.83 & 2427 & 2329 & 501 & 41.1 & 1752.2 & 1879 & 57.5 \\
\hline 18CM10_3D & 0.84 & 1577 & 1371 & 319 & 41.6 & 1088.8 & 1169 & 51.4 \\
\hline & & \multicolumn{7}{c}{ Plane strain conditions } \\
\hline 28CM12_PSC & 0.86 & 292 & 114 & 52 & 44.2 & 152.5 & 215.4 & 14.5 \\
\hline 31CM13_PSC & 0.88 & 518 & 201 & 102 & 42.2 & 273.7 & 376.8 & 13.2 \\
\hline
\end{tabular}

a

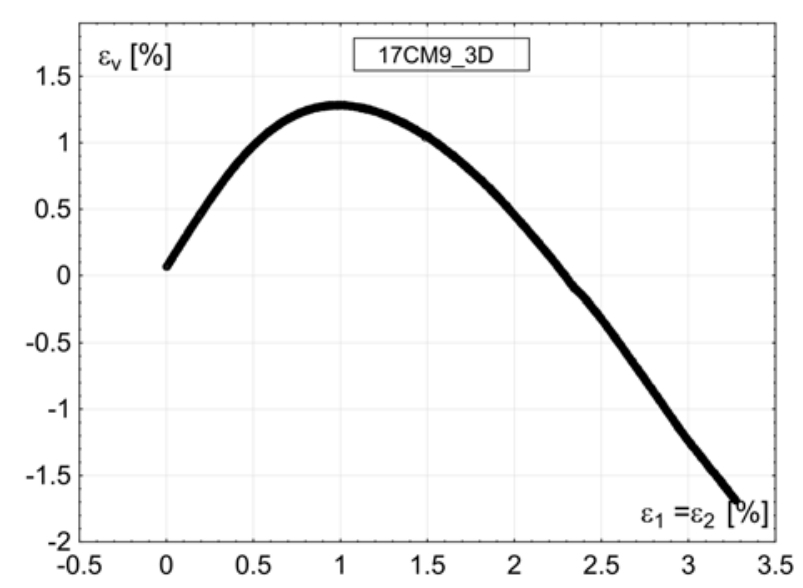

b

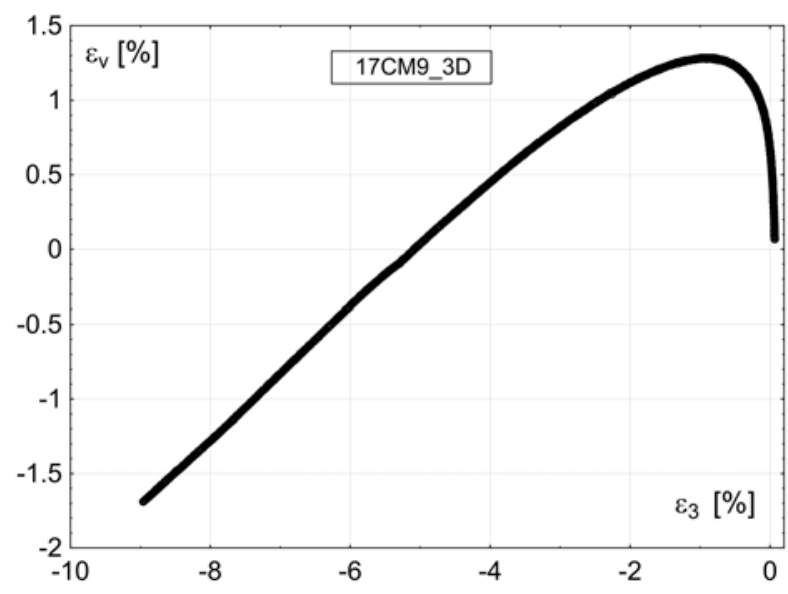

Fig. 15. Relationship: $\varepsilon_{1}-\varepsilon_{v}$ (a) and $\varepsilon_{3}-\varepsilon_{v}$ (b) for the shearing under full $3 \mathrm{D}$ conditions with $\sigma_{3}=$ const $=500 \mathrm{kPa}$

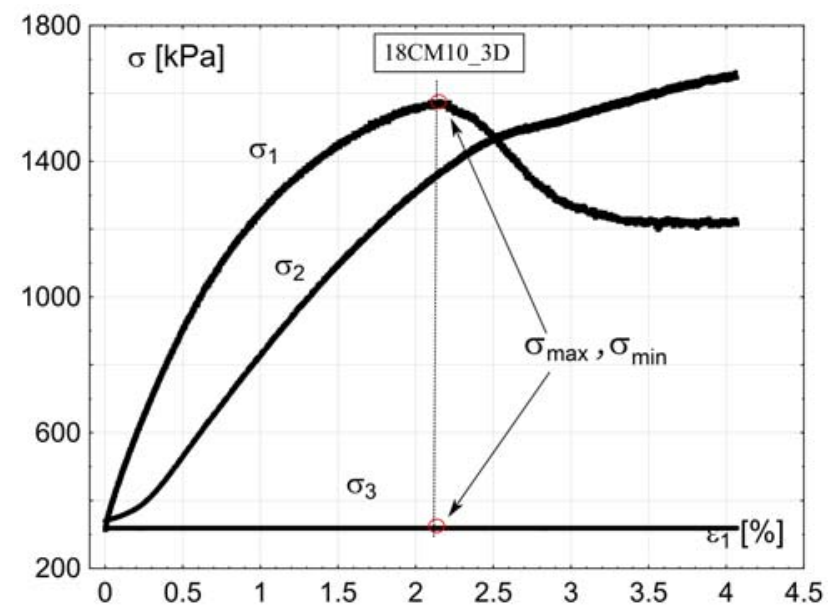

Fig. 16. Stress path leading to the failure state under full $3 \mathrm{D}$ conditions with $\sigma_{3}=$ const $=300 \mathrm{kPa}$ 
a

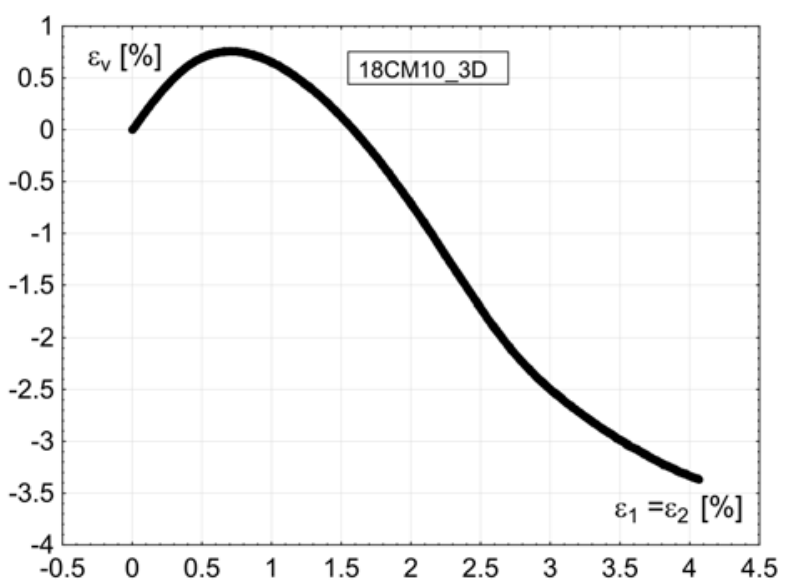

b

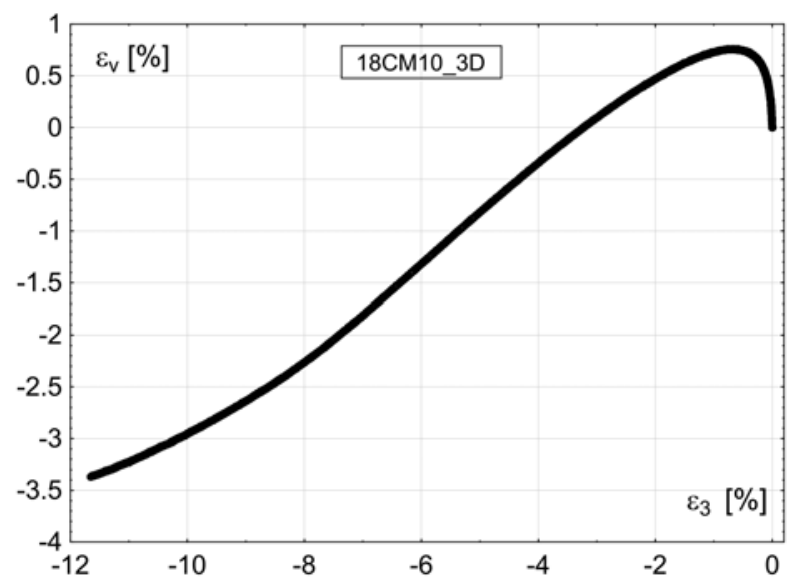

Fig. 17. Relationship: $\varepsilon_{1}-\varepsilon_{v}$ (a) and $\varepsilon_{3}-\varepsilon_{v}$ (b) for the shearing under full $3 \mathrm{D}$ conditions with $\sigma_{3}=$ const $=300 \mathrm{kPa}$

$\left(\sigma_{1}-\sigma_{3}\right)$, plane (because it is destroyed), so the whole load is transmitted in the $x_{2}$ direction. The soil would deform in the $x_{2}$ direction, but it is restricted by the horizontal plates, which also apply load in the $x_{2}$ direction. This observation explains the large increase in the $\sigma_{2}$ stress after reaching the limit state. Figures 15, 17 show the relationships: $\varepsilon_{1}, \varepsilon_{2}-\varepsilon_{v}$ (a) and $\varepsilon_{3}$ $-\varepsilon_{v}$ (b) for 17CM9 3D and 18CM10 3D experiments, respectively. The rate of vertical (in $x_{1}$ direction) and horizontal (in $x_{2}$ direction) deformation was constant and the same: $10 \% \cdot \mathrm{h}^{-1}$, so in this case $\varepsilon_{1}=\varepsilon_{2}$.

\section{ANALYSIS OF RESULTS}

Table 2 presents values of failure stresses for each stress path under given stress conditions. Each failure state corresponds to the friction angle $\varphi^{\prime}$, which is calculated from Eq. (2). $I_{D}^{0}$ denotes the initial density index of soil. The average values of $\varphi^{\prime}$ are the following:

- $39.9^{\circ}$ for axisymmetric conditions,

- $41.4^{\circ}$ for full 3D stress conditions,

- $43.1^{\circ}$ for plane strain conditions.

It can be seen that the highest value of $\varphi^{\prime}$ corresponds to plane strain conditions, and the lowest to axisymmetric conditions. However, according to the theory of the M-C criterion, the friction angle is independent of the stress state of soil. It leads to the conclusion that, in general, this criterion is not sufficient to describe the failure state of soil. The strength of soil is dependent on the stress path that leads to failure. The difference between the highest and the lowest friction angles is $3.2^{\circ}$, which is significant from a practical point of view.

\section{SUMMARY AND CONCLUSIONS}

The experimental results show that, under compression $\left(\sigma_{3}=\right.$ const $)$, the friction angle for soil samples with equal initial density is the highest under plane strain conditions, somewhat smaller under full 3D conditions, and the smallest under axisymmetric conditions. Similar conclusions can be found in earlier publications: Kirkgard and Lade (1993), Lade and Duncan (1975). The Mohr-Coulomb failure criterion is sufficient to describe the failure behaviour of soil under classical triaxial conditions $\left(\sigma_{2}=\sigma_{3}\right)$, but not in general. This dissonance is caused by the fact that the $\mathrm{M}-\mathrm{C}$ condition does not take into account the intermediate stress $\sigma_{2}$. The difference between the highest and the lowest friction angles is $3.2^{\circ}$. Therefore it should be judged whether the friction angle is a material constant or a constitutive model variable.

\section{REFERENCES}

Bishop, A. W. \& Wesley, L. D. (1975). A hydraulic triaxial apparatus for controlled stress path testing. Géotechnique, 25 (4), 657-670. 
Cornforth, D. H. (1964). Some Experiments on the Influence of Strain conditions on the Strength of Sand. Géotechnique, 14 (2), 143-167.

Cudny, M. \& Binder, K. (2005). On shear strength criteria for soils in geotechnics. Inżynieria Morska i Geotechni$k a, 6,456-465$.

GDS EMTAA Handbook (2013).

Green, G. E. (1971). In Roscoe Memorial Symposium: Stress-strain Behaviour of Soils, 285-323.

Hambly, E. C. (1969). A New True Triaxial Apparatus. Géotechnique, 19 (2), 307-309.

Heyman, J. (1972). Coulomb's Memoir on Statics. London: Cambridge University Press.

Lade, P. V. (1978). Cubical Triaxial Apparatus for Soil Testing. ASTM, 1 (2), 93-101.

Lade, P. V. \& Duncan, J. (1973). Cubical Triaxial Tests on Cohesionless Soil. Journal of the Soil Mechanics Foundations Division, ASCE, 99, 793-812.

Lade, P. V. \& Duncan, J. (1974). Elastoplastic Stress-Strain Theory for Cohesionless Soil. Journal of Geotechnical and Geoenvironmental Engineering, 101, 1037-1053.

Lee, K. L. (1970). Comparison of plane strain and triaxial tests on Sand. Journal of the Soil Mechanics Foundations Division, ASCE, 96 (3), 901-923.

Matsuoka, H. \& Nakai, T. (1974). Stress-deformation and strength characteristics of soil under three different principal stresses. Proccedings Japan Society of Civil Engineers, 232, 59-70.

Menzies, B. K. (1988). A computer controlled hydraulic triaxial testing system. ASTM, 977, 82-94.
Rowe, P. W. (1969). The Relation Between the Shear Strength of Sands in Triaxial Compression, Plane Strain and Direct. Géotechnique, 19 (1), 75-86.

Sawicki, A., Sławińska, J., Mierczyński, J. \& Smyczyński, M. (2016). Mechanical properties of sand: triaxial versus plane strain investigations. Archives of Hydro-Engineering and Environmental Mechanics, 63, 2-3, 135-156.

Świdziński, W. (2006). Mechanizmy zagęszczania i uptynniania gruntów sypkich. Gdańsk: IBW PAN.

Świdziński, W. \& Mierczyński, J. (2002). On the measurement of strains in the triaxial test. Archives of HydroEngineering and Environmental Mechanics, 49 (1), 23-41.

Wanatowski, D. \& Chu, J. (2006). Stress-strain behaviour of a granular fill measured by a new plane-strain apparatus. ASTM, 29 (2), 149-157. doi: 10.1520/GTJ12621

Wanatowski, D. \& Chu, J. (2007). Drained behaviour of Changi sand in triaxial and plane-strain compression. Geomechanics and Geoengineering: An International Journal, 2 (1), 29-39.

Kirkgard, M. M. \& Lade, P. V. (1993). Anisotropic three-dimensional behaviour of normally consolidated clay. Canadian Geotechnical Journal, 30 (5), 848-858. doi: 10.1139/t93-075

Yasin, S. J. M., Umetsu, K., Tatsuoka, F., Arthur, J. R. F. \& Dunstan, T. (1999). Plane strain strength and deformation of sands affected by batch variations and different apparatus types. ASTM, 22 (1), 80-100. doi: 10.1520/ GTJ11318J

\section{WARTOŚCI KĄTA TARCIA GRUNTÓW NIESPOISTYCH W RÓŻNYCH STANACH NAPRĘŻENIA}

\section{STRESZCZENIE}

W klasycznym podejściu kąt tarcia wewnętrznego $\varphi^{\prime}$ uznawany jest za cechę fizyczną gruntu. Jego wartość jest wyznaczana na podstawie badań w osiowosymetrycznym stanie naprężenia na podstawie kryterium Coulomba-Mohra. Kryterium to zakłada, że tak wyznaczona wartość kąta tarcia jest stała i niezależna od stanu naprężenia, jakiemu może zostać poddany ten sam grunt. Wartość ta zależy jedynie od początkowego zagęszczenia gruntu. Autorka poddaje weryfikacji doświadczalnej to podejście, w którym przedstawia badania wytrzymałościowe przeprowadzone na gruncie modelowym w różnych stanach naprężenia: osiowosymetrycznym, w pełnym stanie naprężenia 3D oraz w szczególnym stanie 3D: w płaskim stanie odkształcenia.

Słowa kluczowe: prawdziwy aparat trójosiowy, płaski stan odkształcenia, kryterium Coulomba-Mohra 